\title{
RANCANG BANGUN DIGITAL SIGNAGE SEBAGAI PAPAN INFORMASI DIGITAL MASJID DI KOTA PALANGKA RAYA BERBASIS WEB RESPONSIVE
}

\author{
Mochammad Ichsan', Sam'ani², Ferdiyani Haris ${ }^{3}$, M. Haris Qamaruzzaman ${ }^{4}$ \\ Manajemen Informatika', Teknik Informatika², Sistem Informasi ${ }^{3}$ - STMIK Palangkraya \\ IImu Komputer ${ }^{4}$, Universitas Muhammadiyah Palangkaraya \\ Jl. G. Obos No. I I 4 Palangka Raya ${ }^{1,2,3}$, Jl. RTA. Milono Km. I,5 Palangka Raya ${ }^{4}$ \\ Email : salafi_ichsan@yahoo.com', sam.stmikplk@gmail.com²
}

\begin{abstract}
ABSTRAK
Hingga saat ini masih banyak dijumpai pada masjid dalam memberikan informasi seperti jadwal sholat, jadwal kajian, laporan keuangan, himbaun masih menggunakan papan kayu atau triplex sehingga hanya dapat diketahui oleh orang yang masuk atau beribadah dimasjid tersebut serta informasinya pun masih sangat monoton. Masih sedikit masjid yang telah memiliki layar informasi berupa layar televisi yang menyajikan waktu sholat, teks berjalan tentang info kajian, tapi masih terbatas dan belum dilengkapi dengan pamflet kajian dan laporan kas masjid. Kebanyakan masjid di kota Palangka Raya dan sekitarnya yang masih belum memiliki layar informasi karena biaya perangkat yang relatif terlalu mahal sehingga hanya menggunakan papan pengumuman dan kertas yang ditempel pada dinding masjid untuk menampilkan atau menginformasikan jadwal sholat, kajian rutin dan khutbah jumat serta informasi penting lainnya. Sehingga perlu adanya suatu aplikasi alat bantu berupa layar informasi diseluruh masjid-masjid yang ada di Palangka Raya dan sekitarnya yang dapat menampilkan jadwal sholat, kajian rutin dan khutbah jumat serta informasi penting lainnya secara terintegrasi sehingga masyarakat dapat melihat informasi masjid yang diinginkan melalui media smartphone, selain itu pula pengurus atau ta'mir masjid dapat mengelola sendiri konten atau isi media informasi sesuai dengan kebutuhan masjid dengan memanfaatkan Digital signage supaya bentuk penyampaian informasi melalui media display elektronik yang dilakukan secara dinamis dan menarik. Metode yang digunakan dalam penelitian ini adalah dengan menggunakan System Development Life Cycle (SDLC). Pengembangan perangkat lunak (software) menggunakan model pengembangan perangkat lunak Waterfall.
\end{abstract}

Kata kunci : Layar Informasi, Digital Signage, Masjid, Waterfall

\begin{abstract}
Until now, mosques are still often found in providing information such as prayer schedules, study schedules, financial reports, appeals still use wooden boards or triplex so that it can only be known by people who enter or worship at the mosque and the information is still very monotonous. There are still a few mosques that already have information screens in the form of television screens that present prayer times, running texts about study info, but they are still limited and have not been equipped with study pamphlets and mosque cash reports. Most mosques in the city of Palangka Raya and its surroundings still do not have information screens because the cost of the equipment is relatively too expensive, so they only use bulletin boards and paper pasted on the mosque walls to display or inform prayer schedules, routine studies and Friday sermons and other important information. So it is necessary to have a tool application in the form of information screens throughout the mosques in Palangka Raya and its surroundings that can display prayer schedules, regular studies and Friday sermons and other important information in an integrated manner so that people can see the desired mosque information through smartphone media, Besides that, mosque administrators or ta'mir can manage their own content or information media content according to the needs of the mosque by utilizing digital signage so that the form of delivering information through electronic display media is carried out dynamically and attractively. The method used in this research is to use the System Development Life Cycle (SDLC). Software development uses the Waterfall software development model.
\end{abstract}

Keywords : Information Screen, Digital Signage, Mosque, Waterfall

\section{PENDAHULUAN}

Sebuah layar informasi sering dijumpai di jalan-jalan protokol, pusat perbelanjaan, dan instasni baik pemerintah maupun swasta yang digunakan untuk media promosi atau iklan masyarakat, selain itu di masjid juga sudah mulai menggunakan layar informasi, dimana pada layar tersebut menampilkan berbagai macam informasi diantaranya adalah waktu sholat dan jadwal kajian rutin tapi informasi tersebut hanya bisa dilihat oleh orang yang masuk atau beribadah dimasjid tersebut tampilan layar informasi pun masih kurang menarik karena tidak dikombinasi oleh gambar.

Layar informasi adalah salah satu media elektronik yang sering digunakan untuk menyampaikan sebuah informasi yang dibutuhkan, baik dalam dunia industri, lembaga pemerintahan maupun dalam dunia pendidikan.

Banyak masjid di Palangka Raya dan sekitarnya yang masih belum memiliki layar informasi karena biaya perangkat yang relatif terlalu mahal sehingga hanya menggunakan papan pengumuman dan kertas yang ditempel pada dinding masjid untuk menampilkan atau 
Mochammad|chsan, Sam'ani, Ferdiyani Haris, M. Haris Qamaruzzaman. Rancang Bangun Digita/Signage 2021
Sebagai Papan Informasi Digital Masjid Di Kota Palangka Raya Berbasis Web Responsive

menginformasikan jadwal sholat, kajian rutin dan khutbah jumat serta informasi penting lainnya.

Berdasarkan latar belakang pada paragraf sebelumnya maka penulis berinisiatif membuat sebuah penelitian dengan judul "Rancang Bangun Digital Signage Sebagai Papan Informasi Digital Masjid Di Kota Palangka Raya Berbasis Web Responsive". dengan adanya layar informasi ini seluruh masjid-masjid yang ada di Palangka Raya dan sekitarnya dapat menampilkan jadwal sholat, kajian rutin dan khutbah jumat serta informasi penting lainnya secara terintegrasi sehingga masyarakat dapat melihat informasi masjid yang diinginkan melalui media smartphone, selain itu pula pengurus atau ta'mir masjid dapat mengelola sendiri konten atau isi media informasi sesuai dengan kebutuhan masjidnya. Digital signage adalah bentuk penyampaian informasi melalui media display elektronik yang dilakukan secara dinamis dan menarik. Dengan memanfaatkan teknologi LCD, LED dan plasma. Digital signage display dapat menyampaikan informasi secara satu maupun dua arah menggunakan teknologi interaktif.

\section{LANDASAN TEORI \\ Rancang Bangun}

Menurut Pressman dalam Komalasari (2018), perancangan atau rancang merupakan serangkaian prosedur untuk menterjemahkan hasil analisa dan sebuah sistem ke dalam bahasa pemrograman untuk mendeskripsikan dengan detail bagaimana komponenkomponen sistem di implementasikan.

\section{Layar}

Menurut Kamus Besar Bahasa Indonesia Edisi ke Tujuh (20I3), Layar merupakan Bidang (berupa kain, papan, kaca) tempat menayangkan gambar (film, televisi, dan sebagainya).

Menurut Sianulan (20I5), layar LCD (Liquid Cristal Display) adalah salah satu komponen elektronika yang berfungsi sebagai tampilan suatu data, baik karakter, huruf ataupun grafik.

\section{Digital Signage}

Sign atau signage menurut Oxford Andvance Learner Dictionary of Current Engish yang dipaparkan Suryantini (200I) adalah sebuah kata atau kata-kata, desain dan lainlain pada sebuah papan atau lempengan untuk memberikan peringatan atau untuk mengarahkan seseorang menuju sesuatu. Menurut Lawrence K. Frank, arti sign adalah pesan atau informasi yang muncul secara berturut-turut atau teratur dalam hubungannya dengan tanda-tanda yang pentinf atau menimbulkan respon pada manusia.

\section{Informasi}

Menurut Wahyono (2004:12), informasi adalah hasil dari pengolahan data menjadi yang lebih berguna bagi yang menerimanya yang menggambarkan suatu kejadiankejadian nyata dan data digunakan sebagai alat bantu pengambilan suatu keputusan.

Menurut Sutedjo (2002:12), informasi adalah merupakan hasil pengolahan data atau fakta yang dikumpulkan dengan cara tertentu. Informasi disajikan dalam bentuk yang mudah dipahami dan merupakan pengetahuan yang relevan yang dibutuhkan untuk menambah wawasan bagi pemakainya guna mencapai suatu tujuan

\section{Mesjid}

Menurut Al-Qathani (2013:396), secara bahasa, kata masjid (مَسْجِد) adalah tempat yang dipakai untuk bersujud. Kemudian maknanya meluas menjadi bangunan khusus yang dijadikan orang-orang untuk tempat berkumpul menunaikan shalat berjama'ah.

Menurut Rawas dalam Al-Qahthani (2013:397), masjid adalah masjid menurut syara' adalah tempat yang disediakan untuk shalat di dalamnya dan sifatnya tetap, bukan untuk sementara.

\section{Web Mobile}

Menurut Abdurahman (20I6), web mobile adalah lanjutan dari aplikasi web tradisional. Saat online menggunakan smartphone, tablet, atau komputer, desainnya beradaptasi dengan perangkat yang digunakan tersebut. Desain yang fleksibel ini memaksimalkan kemampuan web browser yang digunakan di perangkat mobile yang digunakan.

\section{METODE}

Adapun metode yang digunakan dalam penelitian ini adalah dengan menggunakan System Development Life Cycle (SDLC). Pengembangan perangkat lunak (software) menggunakan model pengembangan perangkat lunak Waterfall. Fase-fase yang dilakukan penulis dengan metode ini adalah :

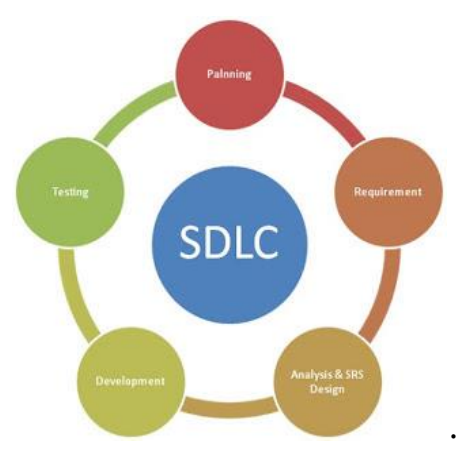

Gambar I. Metode Waterfall (Sumber : Bassil, 2012)

\section{PERANCANGAN SISTEM}

Tahapan perancangan sistem baru berdasarkan data-data yang telah dikumpulkan pada tahap sebelumnya dengan cara merancang perangkat lunak dengan Unified Modeling Language (UML). Gambar 2 berikut merupakan Use case 
diagram yang menjelaskan secara sederhana fungsi sistem dari sudut pandang user .

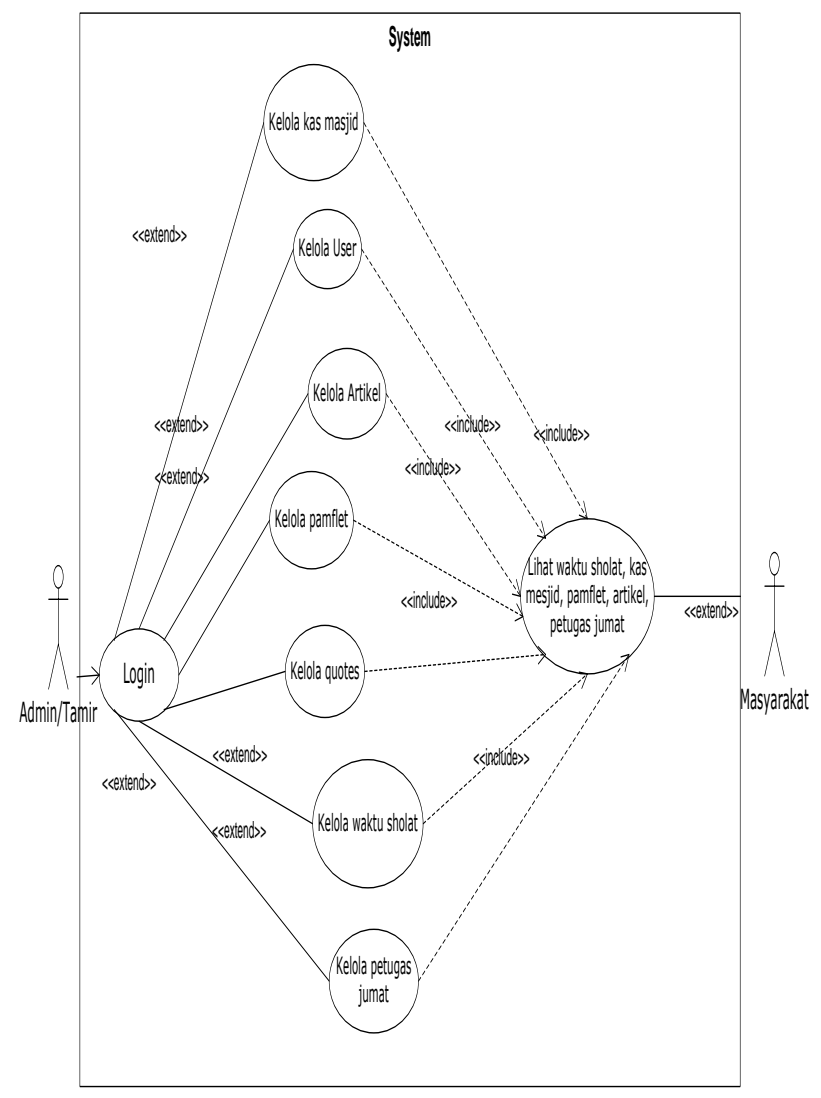

Gambar 2. Use Case Diagram

\section{HASIL DAN PEMBAHASAN}

Dalam media informasi ini akan dijelaskan hasil implementasi yang telah dibuat penulis, yaitu sebagai berikut :

\section{Halaman Pengguna}

Gambar 3 berikut adalah halaman bagi pengguna ketika aplikasi pertama kali dijalankan.

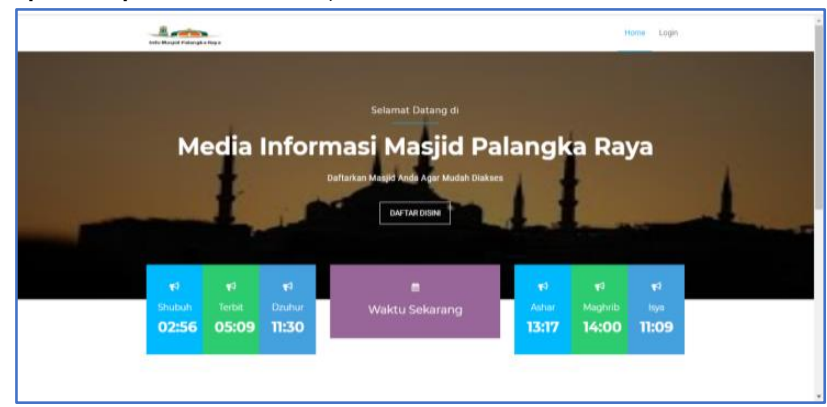

Gambar 3. Halaman Utama Pengguna

\section{Halaman Info Mesjid}

Gambar 4 adalah halaman untuk melihat data info masjid yang terdaftar dalam sistem.

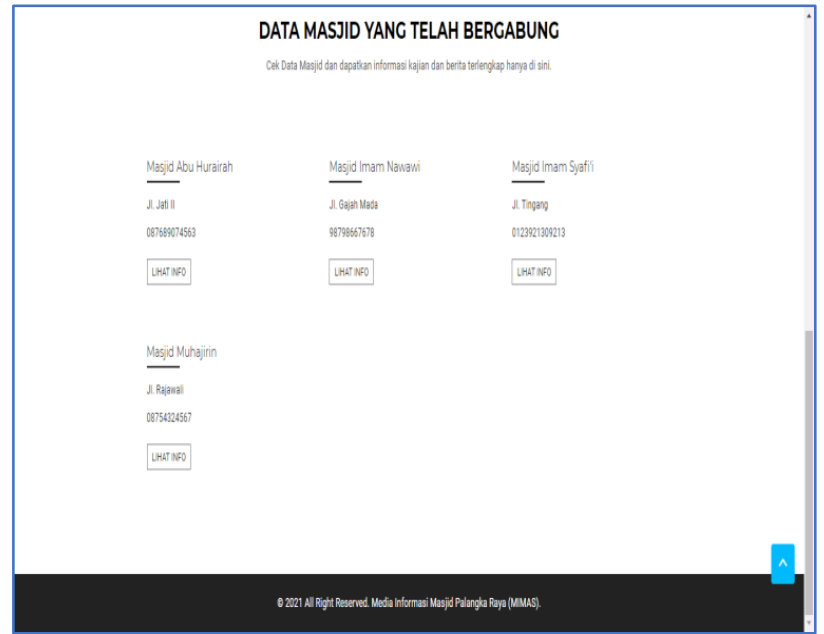

Gambar 4. Halaman Info Mesjid

Jika pengunjung ingin mengetahui info salah satu masjid maka pengunjung dapat memilih tombol lihat info disalah satu masjid yang diinginkan. Maka info masjid yang dipilih akan ditampilkan tersaji pada gambar 5 .

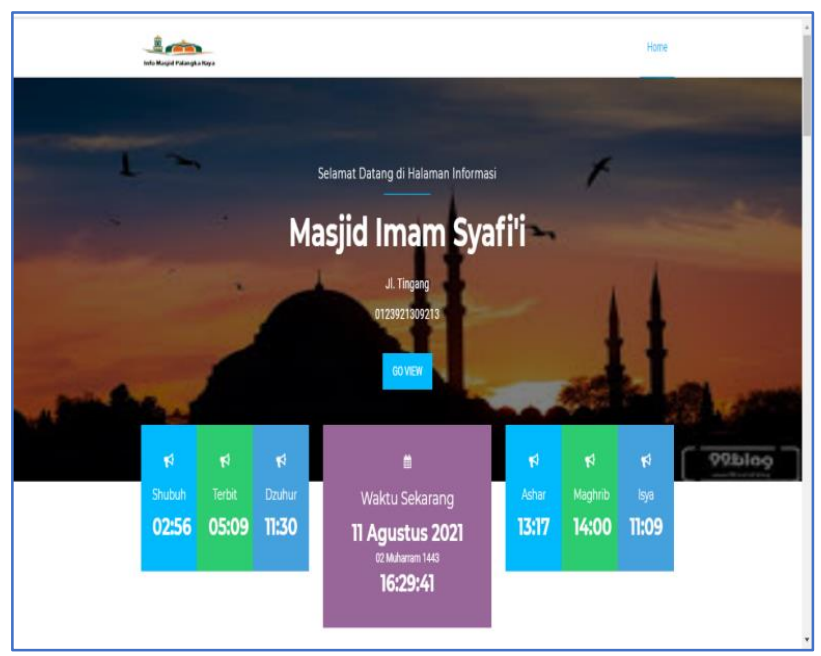

Gambar 5. Info Masjid

\section{Halaman Go View}

Halaman ini digunakan untuk menyajikan informasi lengkap pada layar masjid sehingga informasi dapat tersaji otomatis (slider) terlihat pada gambar 6. 
Mochammadlchsan, Sam'ani, Ferdiyani Haris, M. Haris Qamaruzzaman. Rancang Bangun Digita/Signage

Sebagai Papan Informasi Digital Masjid Di Kota Palangka Raya Berbasis Web Responsive

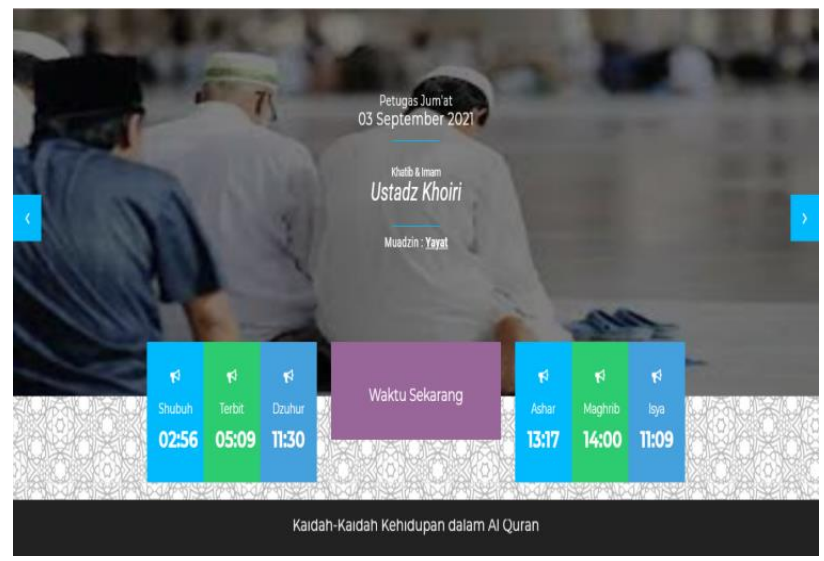

Gambar 6. Halaman Go View

\section{Halaman Pamflet Digital}

Gambar 7 berikut adalah halaman untuk melihat pamflet digital.

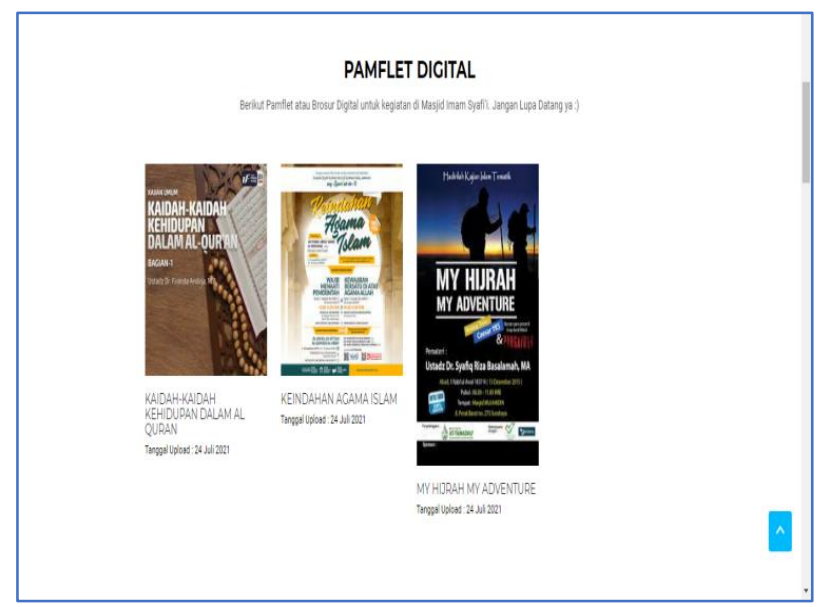

Gambar 7. Halaman Pamflet Digital

\section{Halaman Quotes}

Gambar 8 adalah halaman untuk melihat quotes.

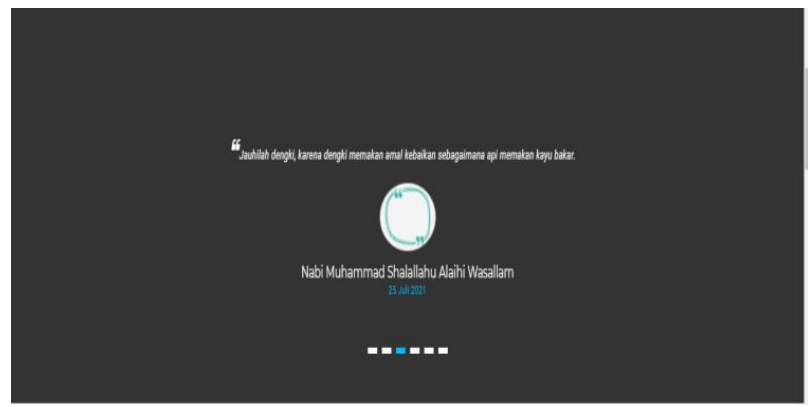

Gambar 8. Halaman Quotes

\section{Halaman Artikel}

Gambar 9 berikut adalah halaman untuk melihat artikel.

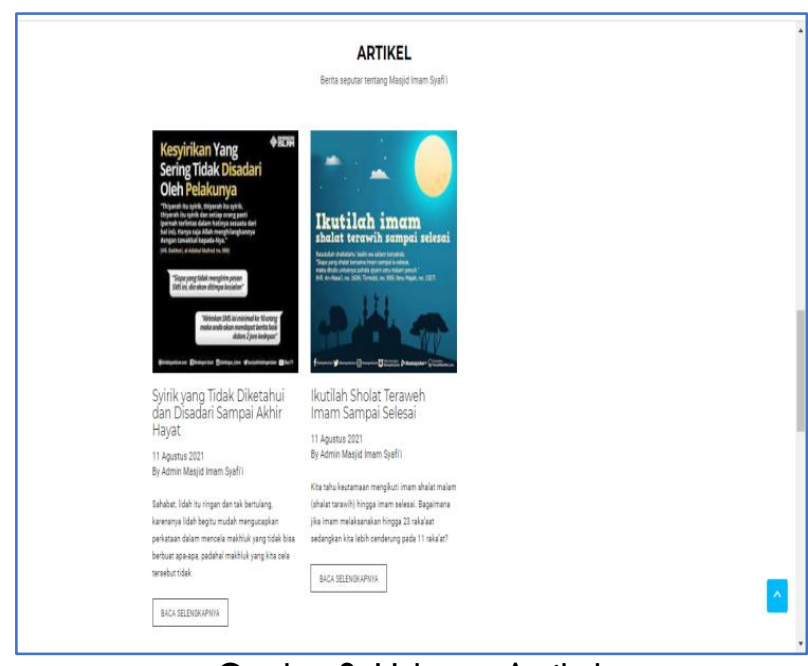

Gambar 9. Halaman Artikel

\section{Halaman Petugas Jum'at}

Gambar 10 adalah halaman untuk melihat data petugas Jum'at.

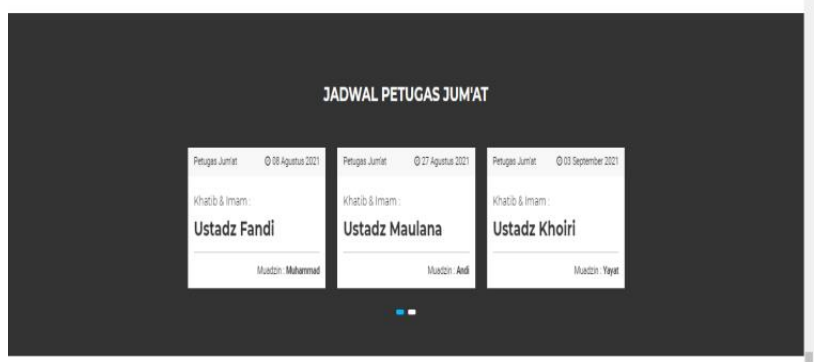

Gambar 10. Halaman Petugas Jum'at

\section{Halaman Data Kas Jum'at Masjid}

Gambar II adalah halaman untuk melihat data kas masjid.

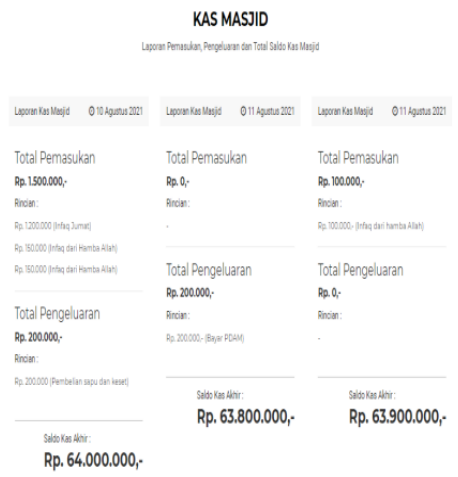

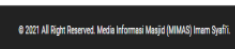

Gambar II. Halaman Data Kas Jum'at Masjid 


\section{Halaman Administrator}

Halaman administrator digunakan admin untuk mengelola data waktu sholat, profil masjid yang mendaftar, quotes (kata-kata bijak) yang diupload pengurus masjid, artikel dari para pengurus masjid, pamflet kajian dari masing-masing masjid, dan data pengguna berupa data pengurus masjid dan validasi pengurus masjid yang mendaftar sehingga dapat menggunakan username dan password yang didaftarkan pada proses pendaftaran. Serta menu logout untuk keluar dari halaman admin atau pengurus masjid. Gambar 12 berikut adalah menu utama halaman administrator.

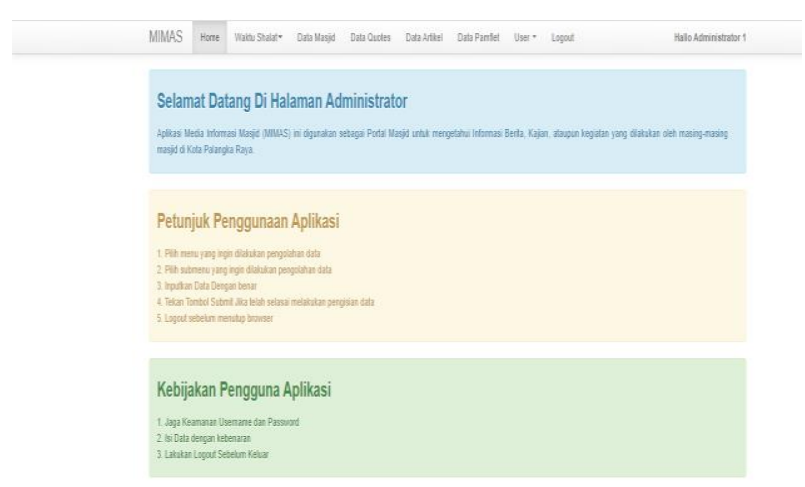

Gambar 12. Halaman Administrator

\section{Simpulan Dan Saran \\ Simpulan}

I. Rancang Bangun Digital Signage Sebagai Papan Informasi Digital Masjid Di Kota Palangka Raya Berbasis Web Responsive merupakan layar informasi bagi seluruh masjid-masjid yang ada di Palangka Raya dan sekitarnya untuk dapat menampilkan jadwal sholat, kajian rutin dan khutbah jumat serta informasi penting lainnya secara terintegrasi sehingga masyarakat dapat melihat informasi masjid yang diinginkan melalui media smartphone, selain itu pula pengurus atau ta'mir masjid dapat mengelola sendiri konten atau isi informasi sesuai dengan kebutuhan masjidnya.

2. Sistem yang dikembangkan ini dibuat secara sederhana dengan tampilan yang mudah digunakan dan dioperasikan baik bagi admin, takmir atau masyarakat sehingga dalam mengelola dan mendapatkan informasi mengenai jadwal sholat, kajian rutin, pamflet, kas masjid, quotes, artikel, kas masjid dan khutbah jumat di wilayah Palangka Raya dan sekitarnya.

\section{Saran}

I. Sistem ini hendaknya lebih ditingkatkan lagi dari segi penyajian informasi yang lebik banyak dan fleksibel berupa pengelolaan zakat, infak online dan lain-lain, sehingga penyajian informasinya dapat lebih baik dan lengkap.

2. Diharapkan sistem ini dapat dioperasikan untuk memudahkan setiap masjid untuk dapat menyajikan informasi kepada masyarakat.

3. Pengembangan aplikasi berbasis android mengenai informasi masjid dan tidak terbatas di daerah Palangka Raya saja

\section{Pustaka Acuan}

Abdurahman, M., 2016. "Sistem Informasi Jadwal Perkuliahan Berbasis Web Mobile pada Politeknik Sains dan Teknologi Wiratama Maluku Utara". Indonesian Journal on Networking and Security Volume 5 No 2 - Mei 2016

Al-Qahthani, Sa'id bin Ali bin Wahf. 2013. Akhlak Bertamu Ke Baitullah, Panduan Lengkap Etika Di Dalam Masjid Edisi Indonesia. Pustaka Ibnu Umar. lakarta.

Ichsan, M., 2019. Aplikasi Cuci Mobil Abc Berbasis Web Mobile. Jurnal Sains Komputer dan Teknologi Informasi. Vol 2 Issue I e-ISSN 2655-7460. https://doi.org//0.33084/jsakti.v2il.II59

Ichsan, M. 2020. Layar Informasi Masjid Imam Syafii Palangka Raya Provinsi Kalimantan Tengah Berbasis Web Mobile. Jurnal Sains Komputer dan Teknologi Informasi. Vol 2 Issue 2 e-ISSN 2655-7460. https://doi.org//0.33084/jsakti.v2i2. 1478

Kamus Besar Bahasa Indonesia Edisi 7. 2013. Kantor Pusat Bahasa. Jakarta

Komalasari, Dinny. 2018. Penerapan Aplikasi Mading Digital Berbasis Web Pada MA. Miftahul Huda Kabupaten Oki. Jurnal Sistem Informasi Volume 2 No. I Juni 20I8. ISSN : $2460-092 X$.

Qamaruzzaman, M, H., Sutami, S., \& Sam'ani, S. (202I). Rancang bangun informasi obat tradisional kalimantan dengan permodelan air terjun berbasis android. Jurnal Pendidikan Informatika dan Sains, IO(I), 80-89. http://dx.doi.org/ 0.3157|/saintek.vI0il.2567

Sam'ani. Rosmiati., Haris, F. 2018. Rancang Bangun Sistem Penjualan Berbasis WEB (Studi Kasus Toko Fauzi Palangka Raya). Jurnal Sains Komputer dan Teknologi Informasi. Vol 3 Issue 2 e-ISSN 26557460. https://doi.org// 0.33084/jsakti.v3i2.2197

Sam'ani. Annisa, S., Heri., 2018. Rancang Bangun Aplikasi Pengawasan Dan Pengendalian Komputer Laboratorium Multimedia STMIK Palangkaraya. Jurnal Sains Komputer dan Teknologi Informasi. Vol I Issue I eISSN 2655-7460. https://doi.org// 0.33084/jsakti.vlil.548

Sam'ani, Qamaruzzaman, M. H, 2019. Rancang Bangun Visualisasi Pembelajaran Berbasis Android Untuk Anak. Jurnal SISTEMASI. Vol 8 No 3 e-ISSN 2540-97I9. https://doi.org//0.32520/stmsi.v8i3.5I8 
Mochammad|chsan, Sam'ani, Ferdiyani Haris, M. Haris Qamaruzzaman. Rancang Bangun Digital Signage

Sebagai Papan Informasi Digital Masjid Di Kota Palangka Raya Berbasis Web Responsive

Sam'ani, Sutami and Qamaruzzaman, M. H. (2019). Implementasi Aplikasi Pembelajaran Untuk Anak Berbasis Android. Martabe : Jurnal Pengabdian Kepada Masyarakat, Vol 2 No 2, p. 106. doi: 10.3 I604/jpm.v2i2. 106-I 10.

Sinaulan, O. M., 20I5. Perancangan Alat Ukur Kecepatan Kendaraan Menggunakan ATMega. E- Journal Teknik Elektro dan Komputer (20I5), ISSN : 230I8402.

Suryantini, Rini. 200I. Sign and Signage System. Fakultasi Teknik Universitas Indonesia. Jakarta.

Sutedjo, B., 2002. Perancangan Dan Pembangunan Sistem Informasi. Andi. Yogyakarta.

Wahyono, T., 2004. Sistem Informasi : Konsep Dasar, Analisis, Desain Dan Implementasi. Graha IImu. Yogyakarta. 